Research Article

\title{
Genetic Diversity Among Pea (Pisum sativum L.) Genotypes for Maturity and Yield Traits
}

\author{
Faiza Aman ${ }^{1, *}$, Neelam Ara ${ }^{1}$ and Syed Mehar Ali Shah ${ }^{2}$ \\ ${ }^{1}$ Department of Horticulture; ${ }^{2}$ Department of Plant Breeding and Genetics, The University of Agriculture, Peshawar, Khyber \\ Pakbtunkhwa, Pakistan.
}



\section{Introduction}

$\mathrm{P}$ (Pisum sativum L.), is leguminous vegetable grown as a garden and field crop throughout the temperate regions of the world (Ceyhan and Avci,
2005). China is the major pea producing country followed by India and USA. It is one of the prominent winter vegetables grown in Pakistan and is cultivated on 26.992 thousand hectares with production of 178.231 thousand tons. Although, it is cultivated in 
various regions of the country and is one of the preferred winter vegetables, but the average green pod yield is quite low $\left(6.60 \mathrm{t} \mathrm{ha}^{-1}\right)$ as compared to that of other pea growing countries of the world where the average production is above $10 \mathrm{t} \mathrm{ha}^{-1}$ (FAOSTAT, 2018).Yield can be increased by using seeds of early flowering and maturing pea genotypes (Bozoglu et al., 2007). Short duration and early varieties of pea have the potential to provide premium returns to the farmers as they can fetch a better price and can be used for multi-cropping (Anant et al., 2006). Pea is grown for its succulent nutritious green seeds and soil fertility benefits. It is a good, inexpensive and a readily available source of proteins, vitamins, minerals, and carbohydrates. Hundred grams edible portion on fresh weight basis contain $308 \mathrm{k}$ cal energy, $18.44 \mathrm{~g}$ protein, $1.4 \mathrm{~g}$ fats, $26 \mathrm{~g}$ fiber, $42.4 \mathrm{~g}$ carbohydrate, 295 $\mathrm{mg}$ phosphorus, $3.5 \mathrm{mg}$ iron, $116 \mathrm{mg}$ magnesium, and $138 \mu \mathrm{g}$ per $100 \mathrm{~g}$ vitamin $\mathrm{B} 9(\mathrm{FAO}, 2016)$.

The presence of genetic variability for the desired characters plays a crucial role in the crop improvement programs to develop desired commercial cultivars (Tiwari and Lavanya, 2012). In pea breeding programs, germplasm displays genetic variation for different morphological traits like days to flowering, vine length, pod length, and seed weight (Pallavi and Pandey, 2013). Crop improvement mainly depends on the extent of heritable diversity existing in crop species. Genetic diversity provides desirable variation among parental genotypes to produce new and valuable combinations (Taran et al., 2005). In order to develop high yielding varieties it is necessary to utilize the existing genetic resources with minimum genetic erosion (Muhammad et al., 2009).

To improve production of garden pea, there is an urgent need of germplasm evaluation for genetic improvement to develop desired high yielding pea genotypes. Yield improvement cannot be solely achieved through direct selection because yield is a trait which depends on various yield-contributing characters (Kumar et al., 2019). The efficiency of selection in any breeding program is enhanced with the knowledge of the association of yield components. Correlation analysis helps in the evaluation of association existing between yield and its contributing traits. Knowledge about the nature and magnitude of genetic diversity in the germplasm and the extent of heritable variation is the basic requirement for the initiation of effective breeding program (Ahmad et al., 2014). The research was therefore designed to assess genetic diversity and the nature of association among yield and its contributing characters for selecting high yielding genotypes of garden pea under natural farming conditions.

\section{Materials and Methods}

Pea germplasm comprising 50 accessions and 7 varieties was obtained from National Agricultural Research Centre (NARC), Islamabad. The germplasm was planted at Horticulture Research Farm, The University of Agriculture, Peshawar during pea growing season 2016-2017.

\section{Experimental design}

Experiment was conducted using randomized complete block design (RCBD). Three replications were used. The treatments (pea genotypes) were randomized within and among blocks (replications).

\section{Sowing of crop}

Seeds of pea genotypes were sown in a three-row plot comprising 8 plants per row. Ridge method was used with a distance of $15 \mathrm{~cm}$ between plants and distance of $45 \mathrm{~cm}$ between rows was maintained. The experimental plot was ploughed thoroughly before seed sowing. A uniform fertilizer dose of $40 \mathrm{~kg} \mathrm{ha}^{-1}$ nitrogen and $50 \mathrm{~kg} \mathrm{ha}^{-1}$ phosphorus in the form of DAP (Di-ammonium phosphate) and $150 \mathrm{~kg} \mathrm{ha}^{-1}$ potassium in the form of potassium sulfate was applied at the time of sowing. Management practices were kept uniform throughout the growing season.

\section{Data collection}

Eight plants were selected randomly from each genotype and were tagged for data collection. Data were collected on days to emergence, days to first picking, plant height, pods plant ${ }^{-1}$, pod length, seeds pod $^{-1}$, hundred green-seeds weight, hundred green-pods weight and green pod yield.

\section{Analysis of data}

Data were collected and then analysed subjected to analysis of variance (ANOVA) technique as outlined by Steel and Torrie (1980) using statistical software STATISTIX 8.1. Correlation coefficients among the quantitative traits were also worked out. Means of each genotype for each trait were standardized before analysis. The standardized data were further subjected to principal component analysis (PCA) to find out dominant traits explaining the variation 
among studied pea genotypes using computer software program Statistica-12. Cluster analysis and pair wise Euclidean distances of pea genotypes were computed on studied traits. The resulting matrices were utilized for the synthesis of cluster diagrams by using the standard procedure with the help of computer software program NTSYSpc 2.10j.

\section{Results and Discussion}

\section{Days to emergence}

Data showed significant variation among all the studied pea germplasm for days to emergence (Table 1). Mean values for days to emergence varied from 9.33 to 15.67 days among studied pea germplasm. The genotype UAP-47 took maximum days to emergence (15.67) followed by UAP-41(15.00). Minimum days to emergence (9.33) were recorded for Leena-Pak variety of pea (Table 2 ).

Table 1: Mean squares of pea genotypes for various morphological traits.

\begin{tabular}{|c|c|c|c|}
\hline Traits & $\begin{array}{l}\text { Replications } \\
(\mathrm{df}=2)\end{array}$ & $\begin{array}{l}\text { Genotypes } \\
(\mathrm{df}=56)\end{array}$ & $\begin{array}{l}\text { Error } \\
(\mathrm{df}=112)\end{array}$ \\
\hline Days to emergenc & 0.023 & $4.53^{* *}$ & 0.47 \\
\hline Days to first picking & 8.44 & $155.41^{*}$ & 1.5 \\
\hline Plant height & 5.41 & $4205.27^{* *}$ & 35.80 \\
\hline Pods plant ${ }^{-1}$ & 12.57 & $43.23^{*}$ & 3.9 \\
\hline Pod length & 0.14 & $5.66^{* *}$ & 0.06 \\
\hline Seeds pod ${ }^{-1}$ & 0.02 & $3.05^{* *}$ & 0.42 \\
\hline 100 green seed weight & 12.15 & $199.58^{* *}$ & 5.31 \\
\hline 100 -green pods weigh & 4.74 & $22817.14^{* *}$ & 20.79 \\
\hline Green pod yield $\left(\mathrm{t} \mathrm{ha}^{-1}\right)$ & 1.41 & $4.63^{* *}$ & 0.26 \\
\hline
\end{tabular}

** = Significant at 1\% level of probability

Shah et al. (2016) reported similar results for days to emergence. They assessed genetic differences among seven pea genotypes including one local cultivar namely Meteor for yield and yield associated characters. They also reported differences among studied material for days to emergence. Genetic differences among garden pea varieties for days to emergence were also reported by Azmat et al. (2011) and Kumar et al. (2016). They also reported a high degree of genetic diversity among pea genotypes for days to emergence. Days to emergence in most of the cases determine crop maturity. The genotypes which take lesser number of days to emergence usually mature earlier. Monpara and Dhameliya (2013) and Kosev (2013) reported that early maturing traits play vital role in the adaptation of genotype to environments and cropping systems and have positive impact on yield. Days to emergence showed significantly positively correlation with days to first picking. It also showed significantly negatively correlation with the length of pod and seeds pod ${ }^{-1}$ (Table 4). Nawab et al. (2008) assessed genetic diversity and correlation between different morphological characters of 12 pea varieties. They also revealed that days to emergence had significantly positive correlation with days to first harvest.

\section{Days to first picking}

Significant $(\mathrm{p} \leq 0.01)$ differences were recorded among studied pea material for days to first picking (Table 1). Data showed that genotype UAP- 29 took maximum days to first picking (88.00) which were statistically at par with four genotypes viz., UAP27 (86.67), UAP-7 (86.33), UAP-22 and UAP- 23 (86.00) genotypes, ranged from 61.67 to 88.00 days (Table 2). Minimum days to first picking were observed for Leena Pak and Meteor each variety taking 61.67 days to first picking.

Days to picking, is an important trait which helps in identifying early, medium and late maturing genotypes. However, earliness of crop maturity is considered best in pea as it protects the plant from biotic and abiotic stresses and therefore exhibits positive effect on yield (Kumar and Abbo, 2001). In the present study, genetic variation among pea germplasm for days to first picking is compatible with the results of Ahmad et al. (2014). They evaluated 12 pea accessions for genetic diversity and observed significant variation among studied material for days to first picking. Genetic variation among 11 pea varieties for first picking has also been confirmed by Rahman et al. (2019).

Days to first picking showed significantly positive association with days to emergence and plant height. It displayed significantly negative correlation with pod length (Table 4). Rahman et al. (2019) conducted correlation and variability studies for 11 genotypes of garden pea and observed significant and positive correlation of days to first picking with plant height and length of pod. The result regarding correlation of days to first picking and pod length is contrary to the findings of the present study. The main reason for this could be the differences among the evaluated pea germplasm and environment. 
Table 2: Means of 57 pea genotypes for days to emergence, days to first picking, plant height, pods plant ${ }^{-1}$ and pod length ( $\mathrm{mm}$ ) at Peshawar during 2017.

\begin{tabular}{|c|c|c|c|c|c|}
\hline $\begin{array}{l}\text { Geno- } \\
\text { types }\end{array}$ & $\begin{array}{l}\text { Days to } \\
\text { emer- } \\
\text { gence }\end{array}$ & $\begin{array}{l}\text { Days } \\
\text { to first } \\
\text { picking }\end{array}$ & $\begin{array}{l}\text { Plant } \\
\text { height } \\
\text { (cm) }\end{array}$ & $\begin{array}{l}\text { Pods } \\
\text { plant }^{-1}\end{array}$ & $\begin{array}{l}\text { Pod } \\
\text { length } \\
\text { (cm) }\end{array}$ \\
\hline UAP-1 & 13.67 & 76.00 & 114.33 & 22.67 & 4.65 \\
\hline UAP-2 & 13.33 & 78.33 & 119.33 & 21.00 & 4.28 \\
\hline UAP- 3 & 14.00 & 81.00 & 120.33 & 24.33 & 4.73 \\
\hline UAP-4 & 15.00 & 65.00 & 48.33 & 20.33 & 7.13 \\
\hline UAP-5 & 14.00 & 78.67 & 63.33 & 25.67 & 4.86 \\
\hline UAP-6 & 14.33 & 75.33 & 80.67 & 21.67 & 7.49 \\
\hline UAP-7 & 12.67 & 86.33 & 99.00 & 26.00 & 6.76 \\
\hline UAP-8 & 15.00 & 76.33 & 72.33 & 21.33 & 7.16 \\
\hline UAP-9 & 14.33 & 82.67 & 107.00 & 21.00 & 4.16 \\
\hline UAP-10 & 14.00 & 73.67 & 122.33 & 24.33 & 4.00 \\
\hline UAP-11 & 14.00 & 71.33 & 122.33 & 22.67 & 4.29 \\
\hline UAP-12 & 14.00 & 80.67 & 105.00 & 21.67 & 4.53 \\
\hline UAP-13 & 14.00 & 82.33 & 123.67 & 22.67 & 3.57 \\
\hline UAP-14 & 14.00 & 82.33 & 92.33 & 21.00 & 4.48 \\
\hline UAP-15 & 14.00 & 82.67 & 102.67 & 21.33 & 4.56 \\
\hline UAP-16 & 14.33 & 81.67 & 148.67 & 25.33 & 5.07 \\
\hline UAP-17 & 14.00 & 80.33 & 146.67 & 23.33 & 5.36 \\
\hline UAP-18 & 14.00 & 75.67 & 139.00 & 23.67 & 4.18 \\
\hline UAP-19 & 14.00 & 77.33 & 71.67 & 20.67 & 4.09 \\
\hline UAP-20 & 14.33 & 76.67 & 130.00 & 23.33 & 4.07 \\
\hline UAP-21 & 14.33 & 83.67 & 182.33 & 24.00 & 5.00 \\
\hline UAP-22 & 14.00 & 86.00 & 146.33 & 24.33 & 5.12 \\
\hline UAP-23 & 14.33 & 86.00 & 135.33 & 22.67 & 3.86 \\
\hline UAP-24 & 14.00 & 80.67 & 165.00 & 20.67 & 4.79 \\
\hline UAP-25 & 14.33 & 80.00 & 99.33 & 21.00 & 5.29 \\
\hline UAP-26 & 14.00 & 74.33 & 153.33 & 24.67 & 4.34 \\
\hline UAP-27 & 14.33 & 86.67 & 140.67 & 21.67 & 5.61 \\
\hline UAP-28 & 14.00 & 82.67 & 112.00 & 20.33 & 5.48 \\
\hline UAP-29 & 11.00 & 88.00 & 175.33 & 35.00 & 6.93 \\
\hline UAP-30 & 14.00 & 83.33 & 100.00 & 20.33 & 3.84 \\
\hline UAP-31 & 12.67 & 78.00 & 152.67 & 25.67 & 5.35 \\
\hline UAP-32 & 14.00 & 80.67 & 158.67 & 29.00 & 5.20 \\
\hline UAP-33 & 15.00 & 82.33 & 65.33 & 18.67 & 5.16 \\
\hline UAP-34 & 15.00 & 80.33 & 54.33 & 21.67 & 6.18 \\
\hline UAP-35 & 12.00 & 83.00 & 127.67 & 26.00 & 6.10 \\
\hline UAP-36 & 14.00 & 65.67 & 146.67 & 25.00 & 6.23 \\
\hline UAP-37 & 14.33 & 74.33 & 162.67 & 26.00 & 5.43 \\
\hline UAP-38 & 14.00 & 84.33 & 124.00 & 23.00 & 5.12 \\
\hline UAP-39 & 13.67 & 82.33 & 75.67 & 21.67 & 4.07 \\
\hline UAP-40 & 14.00 & 66.67 & 67.33 & 21.67 & 4.14 \\
\hline UAP-41 & 15.00 & 62.00 & 47.67 & 19.67 & 4.27 \\
\hline UAP-42 & 14.00 & 80.67 & 83.67 & 23.33 & 6.31 \\
\hline
\end{tabular}

$\begin{array}{llllll}\text { UAP-43 } & 14.00 & 75.67 & 119.00 & 22.67 & 5.10 \\ \text { UAP-44 } & 14.00 & 77.26 & 139.67 & 23.00 & 5.11 \\ \text { UAP-45 } & 14.33 & 64.00 & 118.00 & 28.67 & 4.99 \\ \text { UAP-46 } & 14.00 & 64.00 & 93.67 & 24.00 & 5.22 \\ \text { UAP-47 } & 15.67 & 73.67 & 176.33 & 37.67 & 7.96 \\ \text { UAP-48 } & 14.00 & 77.33 & 156.33 & 25.00 & 7.44 \\ \text { UAP-49 } & 14.00 & 79.33 & 157.00 & 23.00 & 4.68 \\ \text { UAP-50 } & 14.00 & 78.67 & 97.67 & 19.33 & 4.33 \\ \text { Green } & 10.00 & 63.00 & 79.33 & 19.33 & 9.87 \\ \text { Gold } & & & & & \\ \text { Leena Pak } & 9.33 & 61.67 & 68.00 & 17.67 & 8.02 \\ \text { Polo } & 10.33 & 68.33 & 62.00 & 20.00 & 7.28 \\ \text { Meteor } & 13.00 & 61.67 & 55.67 & 17.33 & 8.02 \\ \text { Dogan } & 13.67 & 73.67 & 53.67 & 16.67 & 5.60 \\ \text { Climax } & 15.00 & 82.00 & 81.67 & 18.33 & 7.99 \\ \text { Rizwaan } & 10.67 & 66.00 & 61.33 & 15.00 & 6.99\end{array}$

Grand Mean 13.7376 .88110 .9522 .7754 .71

LSD at $1 \% 1.472 .6212 .804 .265 .07$

\section{Plant height $(\mathrm{cm})$}

Significant $(\mathrm{p} \leq 0.01)$ differences among the genotypes of pea were noted for plant height (Table 1). The data for plant height varied between 47.67 and $182.33 \mathrm{~cm}$ among genotypes of pea. The highest value for plant height was recorded for genotype UAP-21 $(182.33 \mathrm{~cm})$, which was statistically congruent to the genotypes UAP-47 (176.33 cm), UAP-29 (175.33) and UAP-24 $(165.00 \mathrm{~cm})$. However, genotypes UAP41 and UAP-4 attained minimum plant height of $47.67 \mathrm{~cm}$ and $48.33 \mathrm{~cm}$, respectively (Table 2 ).

Plant height is one of the important traits which determine the yield of particular crop. The tested pea genotypes showed ample genetic variation for plant height. The possible reason for this could be attributable to the variability in the genetic constitution of genotypes. The present findings are in harmony with that of Shah et al. (2016). They assessed six commercial pea varieties of different origin for various horticultural traits and reported differences among studied varieties for this parameter. Similarly, Bashir et al. (2019) evaluated nine landraces of garden pea for genetic variation and reported that the studied landraces varied significantly from one another with respect to plant height. Genetic variation among pea genotypes for plant height has also been reported by Azmat et al. (2011); Khan et al. (2013); Ramzan et al. (2014); Dar et al. (2017) and Singh et al. (2019).

Association of plant height was observed positive 
with days to first picking, pods plant ${ }^{-1}$, hundred green seeds weight and green pod yield (Table 4). Ali et al. (2019) assessed 10 pea genotypes for genetic differences and correlation studies. They also reported positive relationship of plant height with pods plant ${ }^{-}$ ${ }^{1}$ and 100-green seeds weight. Similarly, Ramzan et al. (2014) also revealed positive correlation of plant height with pods plant ${ }^{-1}$, length of pod and seeds pod ${ }^{1}$ while evaluating 13 pea genotypes for yield and its contributing traits.

Table 3: Means of 57 pea genotypes for seeds pod ${ }^{-1}$, 100-green seed weight (g), 100- green pod weight (g) and green pod yield $\left(t h a^{-1}\right)$ at Peshawar during 2017.

\begin{tabular}{|c|c|c|c|c|}
\hline $\begin{array}{l}\text { Geno- } \\
\text { types }\end{array}$ & $\begin{array}{l}\text { Seeds } \\
\text { pod }^{-1}\end{array}$ & $\begin{array}{l}\text { 100-green } \\
\text { seed } \\
\text { weight }(g)\end{array}$ & $\begin{array}{l}\text { 100- green } \\
\text { pod weight } \\
\text { (g) }\end{array}$ & $\begin{array}{l}\text { Green pod } \\
\text { yield } \\
\left(\mathrm{t} \mathrm{ha}^{-1}\right)\end{array}$ \\
\hline UAP-1 & 5.00 & 32.00 & 336.33 & 5.69 \\
\hline UAP-2 & 5.67 & 23.33 & 357.67 & 6.49 \\
\hline UAP- 3 & 5.33 & 34.33 & 361.33 & 6.70 \\
\hline UAP-4 & 6.67 & 36.33 & 423.67 & 6.87 \\
\hline UAP-5 & 6.33 & 26.33 & 415.33 & 6.62 \\
\hline UAP-6 & 7.33 & 48.00 & 541.33 & 6.59 \\
\hline UAP-7 & 7.00 & 43.00 & 537.00 & 7.29 \\
\hline UAP-8 & 6.67 & 47.67 & 436.67 & 6.61 \\
\hline UAP-9 & 5.33 & 30.67 & 341.33 & 5.77 \\
\hline UAP-10 & 5.67 & 27.67 & 339.67 & 6.47 \\
\hline UAP-11 & 4.67 & 25.33 & 264.33 & 5.62 \\
\hline UAP-12 & 5.00 & 27.33 & 321.33 & 6.78 \\
\hline UAP-13 & 5.67 & 27.67 & 333.67 & 6.01 \\
\hline UAP-14 & 6.67 & 29.00 & 356.67 & 6.33 \\
\hline UAP-15 & 6.33 & 29.33 & 346.00 & 6.66 \\
\hline UAP-16 & 5.33 & 32.33 & 340.00 & 6.54 \\
\hline UAP-17 & 5.33 & 47.33 & 349.00 & 5.41 \\
\hline UAP-18 & 5.67 & 40.67 & 367.67 & 5.18 \\
\hline UAP-19 & 6.33 & 29.00 & 340.67 & 5.79 \\
\hline UAP-20 & 5.00 & 28.33 & 338.00 & 4.71 \\
\hline UAP-21 & 6.00 & 35.33 & 375.33 & 6.39 \\
\hline UAP-22 & 6.33 & 35.33 & 392.33 & 5.78 \\
\hline UAP-23 & 5.67 & 21.00 & 298.00 & 5.19 \\
\hline UAP-24 & 6.67 & 28.33 & 326.67 & 6.47 \\
\hline UAP-25 & 6.67 & 33.67 & 321.33 & 6.29 \\
\hline UAP-26 & 5.33 & 26.00 & 285.00 & 5.75 \\
\hline UAP-27 & 6.33 & 34.33 & 354.33 & 5.32 \\
\hline UAP-28 & 6.67 & 31.67 & 316.67 & 6.96 \\
\hline UAP-29 & 6.67 & 53.67 & 554.33 & 9.34 \\
\hline UAP-30 & 4.33 & 24.67 & 224.33 & 5.55 \\
\hline UAP-31 & 5.67 & 42.33 & 528.33 & 7.64 \\
\hline UAP-32 & 5.33 & 36.33 & 487.00 & 7.44 \\
\hline
\end{tabular}

\begin{tabular}{|c|c|c|c|c|}
\hline UAP-33 & 4.67 & 25.00 & 282.67 & 5.42 \\
\hline UAP-34 & 6.00 & 35.67 & 429.00 & 6.86 \\
\hline UAP-35 & 7.00 & 54.00 & 542.33 & 7.69 \\
\hline UAP-36 & 6.00 & 36.00 & 395.67 & 6.39 \\
\hline UAP-37 & 5.33 & 27.67 & 307.00 & 5.94 \\
\hline UAP-38 & 4.67 & 32.67 & 280.67 & 5.1 \\
\hline UAP-39 & 4.00 & 28.67 & 241.33 & 4.82 \\
\hline UAP-40 & 5.67 & 26.33 & 303.00 & 5.18 \\
\hline UAP-41 & 5.33 & 35.00 & 410.33 & 6.43 \\
\hline UAP-42 & 7.00 & 35.33 & 422.33 & 6.56 \\
\hline UAP-43 & 6.67 & 36.67 & 414.00 & 6.46 \\
\hline UAP-44 & 6.00 & 32.67 & 421.33 & 6.35 \\
\hline UAP-45 & 6.00 & 38.00 & 438.33 & 6.54 \\
\hline UAP-46 & 4.67 & 33.67 & 391.00 & 6.94 \\
\hline UAP-47 & 7.00 & 57.33 & 574.00 & 10.19 \\
\hline UAP-48 & 5.00 & 40.00 & 294.33 & 5.25 \\
\hline UAP-49 & 5.33 & 46.00 & 281.33 & 4.96 \\
\hline UAP-50 & 5.33 & 30.33 & 279.33 & 4.67 \\
\hline $\begin{array}{l}\text { Green } \\
\text { Gold }\end{array}$ & 9.33 & 42.00 & 583.00 & 5.91 \\
\hline Leena Pak & 7.67 & 39.00 & 433.33 & 5.62 \\
\hline Polo & 5.67 & 26.33 & 292.67 & 4.29 \\
\hline Meteor & 8.00 & 32.33 & 412.00 & 4.11 \\
\hline Dogan & 5.33 & 23.67 & 383.00 & 4.36 \\
\hline Climax & 8.33 & 32.67 & 422.67 & 5.13 \\
\hline Rizwaan & 6.00 & 25.33 & 256.67 & 4.19 \\
\hline
\end{tabular}

Grand Mean 5.98 34.05 375.49 6.25

LSD at $1 \% 1.394 .939 .761 .10$

\section{Pods plant ${ }^{-1}$}

Data showed significant differences $(\mathrm{p} \leq 0.01)$ among genotypes of pea for number of pods plant ${ }^{-1}$ (Table 1). Pods plant ${ }^{-1}$ ranged from 15.00 to 37.67 among studied pea germplasm. Mean data for pods plant ${ }^{-1}$ indicated that, maximum value for pods plant ${ }^{-1}$ were recorded for genotype UAP-47 (37.67) which was at par with UAP- 29 (35.00), while minimum pods plant $^{-1}(15.00)$ were recorded for pea variety Rizwaan (Table 2) .

The results depicted significant differences among the investigated genotypes of pea for pods plant ${ }^{-1}$. Kumar et al. (2016) also obtained similar results. They evaluated fifty four genotypes of pea including four check cultivars for important horticultural traits and observed significant variation among studied material for pods plant ${ }^{-1}$. Rahman et al. (2019) have also observed variation among eleven pea genotypes for pods plant ${ }^{-1}$. Similarly, Dar et al. (2017) in a study of 
six diverse genotypes of pea also reported significant variation in the studied material for pods plant ${ }^{-1}$.

Pods plant ${ }^{-1}$ exhibited positive correlation with plant height, hundred green seeds weight, hundred green pods weight and green pod yield (Table 4). Number of pods plant ${ }^{-1}$ contributes directly towards increase in the fresh pod yield. Yadav et al. (2018) suggested that genotypes which produce more healthy pods can be used to increase the production of pea. The findings of the study are in agreement with that of Singh et al. (2019). They studied 55 genotypes of pea for evaluating interrelationship among yield and yield-related characters. In their study, pods plant ${ }^{-1}$ showed significantly positive correlation with green pod weight, seed weight and green pod yield.

\section{Pod length (cm)}

Significant $(\mathrm{p} \leq 0.01)$ differences among studied material for pod length were revealed for the mean data for length of pod (Table 1). Pod length varied from 3.57 to $9.87 \mathrm{~cm}$ among genotypes of pea. Maximum pod length $(9.87 \mathrm{~cm})$ was recorded for variety Green Gold followed by Meteor and Leena Pak each having $8.02 \mathrm{~cm}$ of pod length. Minimum pod length (3.57 $\mathrm{cm}$ ) was recorded for genotype UAP-13 (Table 2).

Significant variation among genotypes of pea for pod length is similar with the findings of Khan et al. (2013). They reported similar variation for pod length among 13 genotypes of pea. The observations are also in line with the findings of Singh et al. (2019) and Bashir et al. (2019). Singh et al. (2019) assessed 55 genotypes of pea and observed sufficient genetic diversity among them for yield and yield related traits. Similarly, Bashir et al. (2019) investigated nine pea landraces collected from mountainous areas using one cultivar (Meteor) as control. There was high variation among the landraces in the content of pod length.

Pod length revealed significantly positive association with seeds pod $^{-1}$, hundred green seeds weight, hundred green pods weight and green pod yield (Table 4), suggesting longer pods with more number of seeds which would ultimately result in increased yield. However, pod length displayed significantly negative correlation with days to emergence and days to first picking. Similar trend of positive correlation was observed by Smitchger and Weeden (2018). They reported that increase in pod length increases the number of seeds pod ${ }^{-1}$ and pod length is therefore important trait determining the yield. They also revealed that genotypes producing longer pods are desirable if they have more seeds in their pods compared to those producing short pods. Ramzan et al. (2014) have also supported the results of the present study. In their study, pod length was significantly positively associated with number of seeds $\operatorname{pod}^{-1}$ and fresh weight of pea. Similarly, Rahman et al. (2019) also reported positive correlation of pod length with number of seeds pod ${ }^{-1}$ and number of pods plant ${ }^{-1}$.

\section{Seeds pod ${ }^{-1}$}

Data for seeds pod $^{-1}$ showed significant $(p \leq 0.01)$ differences amongst studied pea genotypes (Table 1 ). Mean data for seeds pod ${ }^{-1}$ among different genotypes ranged from 4.00 to 9.33 . Highest number of seeds $\operatorname{pod}^{-1}$ (9.33) was recorded for Green Gold which was statistically at par with Climax (8.33) and Meteor (8.00). Minimum number of seeds $\operatorname{pod}^{-1}(4.00)$ was recorded for genotype UAP-39 (Table 3).

Table 4: Correlation among various morphological traits of garden pea.

\begin{tabular}{|c|c|c|c|c|c|c|c|c|c|}
\hline Traits & DTE & DFP & PH & PPP & PL & SPP & HGSW & HGPW & GPY \\
\hline DTE & 0.00 & $0.29^{*}$ & 0.14 & 0.16 & $-0.43^{* *}$ & $-0.32^{*}$ & -0.11 & -0.20 & 0.12 \\
\hline DFP & & 0.00 & $0.42^{* * *}$ & 0.24 & $-0.38^{* *}$ & -0.21 & 0.01 & -0.13 & 0.19 \\
\hline $\mathrm{PH}$ & & & 1.00 & $0.67^{* *}$ & -0.21 & -0.18 & $0.29^{*}$ & 0.05 & $0.35^{\text {** }}$ \\
\hline PPP & & & & 1.00 & 0.00 & -0.06 & $0.54^{* *}$ & $0.45^{* *}$ & $0.74^{* * *}$ \\
\hline PL & & & & & 1.00 & $0.71^{* *}$ & $0.52^{* *}$ & $0.58^{* *}$ & 0.15 \\
\hline SPP & & & & & & 1.00 & $0.41^{* *}$ & $0.66^{* *}$ & 0.23 \\
\hline HGSW & & & & & & & 1.00 & $0.72^{* *}$ & $0.57^{\text {** }}$ \\
\hline HGPW & & & & & & & & 1.00 & $0.66^{* *}$ \\
\hline GPY & & & & & & & & & 1.00 \\
\hline
\end{tabular}

DTE: Days to emergence; DFP: Days to first picking; PH: Plant height; PPP: Pods plant ${ }^{-1}$; PL: Pod length; SPP: Seeds pod ${ }^{-1}$; HGSW: Hundred green seeds weight; HGPW: Hundred green pods weight; GPY: Green pod yield 
Seeds pod $^{-1}$ is a very crucial yield contributing trait which has positive impact on pea yield. Significant variation for seeds pod $^{-1}$ among pea genotypes indicated the existence of considerable variability. Smitchger and Weeden (2018) reported that seeds pod $^{-1}$ increased with increasing length of pod while examining the relationship between seed size and yield in pea. Bhuvaneswari et al. (2016) investigated 51 diverse pea genotypes for nine yield related quantitative traits and reported significant variation among the genotypes for seeds $\operatorname{pod}^{-1}$. Kumar et al. (2016), Dar et al. (2017) and Singh et al. (2019) also have similar results of genetic differences for seeds pod $^{-1}$.

Seeds pod $^{-1}$ revealed significantly positive correlation with pod length, hundred green seeds weight and hundred green pods weight (Table 4). However, it displayed significantly negative correlation with days to emergence. Nearly similar trend was also reported by of Bhuvaneswari et al. (2016). The results are also compatible with the work of Bashir et al. (2019), Ramzan et al. (2014) and Rahman et al. (2019). Their results of correlation between traits showed that number of seeds pod $^{-1}$ displayed significantly positive correlation with pod length, pods plant ${ }^{-1}$ and fresh pod weight.

\section{Hundred green seeds weight $(g)$}

Significant $(\mathrm{p} \leq 0.01)$ differences among studied pea germplasm were observed for 100- green seeds weight (Table 1). Hundred green seeds weight among genotypes varied between 21.00 to 57.33 g. Maximum hundred green seeds weight (57.33 g) was recorded for genotype UAP-47 which was statistically at par with genotype UAP-35 (54.00 g) and genotype UAP-29 (53.67 g). Minimum value for hundred green seeds weight $(21.00 \mathrm{~g})$ was recorded for genotype UAP-23 (Table 3).

Data showed considerable differences among pea genotypes for hundred green seeds weight. The possible reason for such genetic diversity might be due to differences in the genetic makeup of genotypes. The results of the present study are in harmony with the findings of Azmat et al. (2011) and Bhuvaneswari et al. (2016). Azmat et al. (2011) reported a lot of variation among 146 pea accessions for 100-green seed weight and suggested the use of this trait for efficient characterization of pea germplasm. Similarly, Bhuvaneswari et al. (2016) evaluated 51 diverse pea genotypes for quantitative and qualitative traits and re- ported considerable genetic variation among studied genotypes for 100-green seed weight.

Hundred green seeds weight manifested significantly positive association with plant height, pods plant ${ }^{-1}$ seeds pod $^{-1}$, pod length, 100-green pod weight and green pod yield (Table 4). Lakic et al. (2019) reported that this character is considered a yield contributing trait in garden pea that directly determines the yield of the crop. Positive correlation among yield traits is also reported by Bhuvaneswari et al. (2016). They observed significantly positive association of hundred green seeds weight with the number of pods plant ${ }^{-1}$, number of seeds pod $^{-1}$, hundred seeds weight and seed yield plant ${ }^{-1}$ both at phenotypic and genotypic levels. Singh and Srivastava (2015) also reported significant correlation between hundred green seeds weight and pod yield plant ${ }^{-1}$ among tall as well as dwarf pea genotypes.

\section{Hundred green pods weight (g)}

Data regarding hundred green pods weight showed significant $(\mathrm{p} \leq 0.01)$ differences among genotypes of pea (Table 1). Hundred green pods weight among genotypes was in the range of 225.33 to $583.00 \mathrm{~g}$. Maximum hundred green pods weight $(583.00 \mathrm{~g})$ was recorded for genotype green gold which was at par with genotype UAP-47 (574.00 g). Minimum hundred green pods weight (224.33 g) was recorded for genotype UAP-30.

Habtamu and Million (2013) reported differences among studied pea accessions for hundred green pods weight. They also observed large magnitude of variability among genotypes for 100-green pod weight in their study comprising 13 pea genotypes along with two commercial varieties. Similarly, Sharma and Bora (2013) also reported a good amount of genetic variation among 39 genotypes of garden pea for 100-pods weight.

Hundred green pods weight showed positive correlation with pods plant $^{-1}$, pod length, seeds pod $^{-1}$, 100 -green seed weight and green pod yield (Table 4). This suggested that these traits can be advantageously used for improving yield in garden pea. Similar trend of correlation among these characters for garden pea has also been previously reported by Rahman et al. (2019). In contrast to these findings, Bashir et al. (2014) observed significantly negative correlation of pod weight with seed pod $^{-1}$, productive branches plant $^{-1}$, pod length and yield plant ${ }^{-1}$. 
Green pod yield $\left(t h a^{-1}\right)$

Data showed significant $(\mathrm{p} \leq 0.01)$ differences among genotypes of pea for green pod yield (Table 1). Green pod yield among genotypes varied from 4.11 to 10.19 tons. Maximum green pod yield (10.19 tons) was produced by genotype UAP-47 which was statistically at par with genotype UAP-29 (9.34 tons). The genotype Meteor produced minimum green pod yield (4.11 tons) (Table 3).

The studied material displayed significant variation for green pod yield. This might be due to variation in the genetic makeup of genotypes. Ali et al. (2007) evaluated 153 local and exotic genotypes of pea for 27 morphological traits and also reported high magnitude of variation among studied pea genotypes for green pod yield. Similarly, Muhammad et al. (2009) and Singh et al. (2019) also reported variability among pea genotypes for green pod yield. Muhammad et al. (2009) investigated the extent of genetic diversity in 263 genotypes of Pisum sativum and reported ample genetic variation among them for green pod yield. A total of fifty-five pea genotypes were evaluated by Singh et al. (2019) using eleven morphological traits. Based on analysis of variance, all the studied genotypes showed significant differences for green pod yield, indicating the presence of sufficient variability for the trait among studied material.

Green pod yield manifested significantly positive correlation with plant height, pods plant ${ }^{-1}$, pod length, 100-green seed weight and 100-green pod weight (Table 4), indicating the importance of these traits in the improvement of green pod yield of garden pea. Similar trend was reported by Singh et al. (2019). They also observed positive association among pod length, pod width, seeds pod $^{-1}$ and green pod yield. Similarly, Rahman et al. (2019) also observed positive correlation of pod yield with plant height, pod length, pods plant ${ }^{-1}$ and seeds pod ${ }^{-1}$.

\section{Principal component analysis}

The principal component analysis (PCA) was performed to study the pattern of variation among 57 pea genotypes for 9 quantitative traits. The analysis revealed that the first five principal components had Eigen values of more than 1 explaining $78.9 \%$ of the total variation (Table 5). The first and second principal components namely $\mathrm{PC}_{1}$ and $\mathrm{PC}_{2}$ contributed $29.9 \%$ and $54.2 \%$ of the total variation, respectively. The $\mathrm{PC}_{1}$ was characterized by pods plant ${ }^{-1}$, green pod yield, plant height and 100-green seed weight. The second principal component $\left(\mathrm{PC}_{2}\right)$ was dominated by pod length, 100-green pod weight, seeds pod $^{-1}$, 100-green seed weight and days to first picking ( $\mathrm{Ta}^{-}$ ble 6).These results are in agreement with the findings of Gixhari et al. (2014). They also observed that the traits like seeds pod ${ }^{-1}, 100$-seed weight and seed yield contributed to the overall variation among the 132 pea accessions. Umar et al. (2014) studied the pattern of genetic diversity among 128 exotic pea accessions for eleven quantitative attributes. They observed that weight pod $^{-1}$, seed weight, pod weight, seed weight pod $^{-1}$, number of pods plant ${ }^{-1}$ and total pod number, pod thickness and pod length dominated the first principal component and contributed to the $40.29 \%$ of the total variation. Similarly, Esposito et al. (2009) reported that the first two components explained $67.7 \%$ and $69.8 \%$ of variability. In the reported study, they observed that pod length and number of days to picking explained most of the variation in the pea germplasm.

Table 5: Eigen values of principal components (PCs) for quantitative traits of garden pea genotypes.

\begin{tabular}{lllll} 
PCs & $\begin{array}{l}\text { Eigen } \\
\text { Values }\end{array}$ & $\begin{array}{l}\text { \% Total } \\
\text { variance }\end{array}$ & $\begin{array}{l}\text { Cumulative } \\
\text { Eigen value }\end{array}$ & $\begin{array}{l}\text { Cumulative } \\
\text { \% variance }\end{array}$ \\
\hline PC1 & 5.1 & 29.9 & 5.1 & 29.9 \\
PC2 & 4.1 & 24.2 & 9.2 & 54.2 \\
PC3 & 1.7 & 10.0 & 10.9 & 64.1 \\
PC4 & 1.5 & 8.6 & 12.4 & 72.7 \\
PC5 & 1.1 & 6.2 & 13.4 & 78.9 \\
PC6 & 0.8 & 4.4 & 14.2 & 83.4 \\
PC7 & 0.7 & 3.9 & 14.8 & 87.2 \\
PC8 & 0.5 & 3.1 & 15.4 & 90.3 \\
PC9 & 0.4 & 2.1 & 15.7 & 92.4 \\
PC10 & 0.3 & 2.0 & 16.1 & 94.5 \\
PC11 & 0.2 & 1.3 & 16.3 & 95.8 \\
PC12 & 0.2 & 1.2 & 16.5 & 96.9 \\
PC13 & 0.2 & 1.0 & 16.6 & 97.9 \\
PC14 & 0.1 & 0.7 & 16.8 & 98.7 \\
PC15 & 0.1 & 0.6 & 16.9 & 99.3 \\
PC16 & 0.1 & 0.4 & 17.0 & 99.8 \\
PC17 & 0.0 & 0.2 & 17.0 & 100.0 \\
\hline
\end{tabular}

\section{Cluster analysis for quantitative traits}

Cluster analysis was performed to observe the clustering pattern of pea genotypes on the basis of quantitative traits. The Euclidean distance was used as a measure of genetic distance among pea genotypes. Euclidean distance among pea genotypes ranged from 


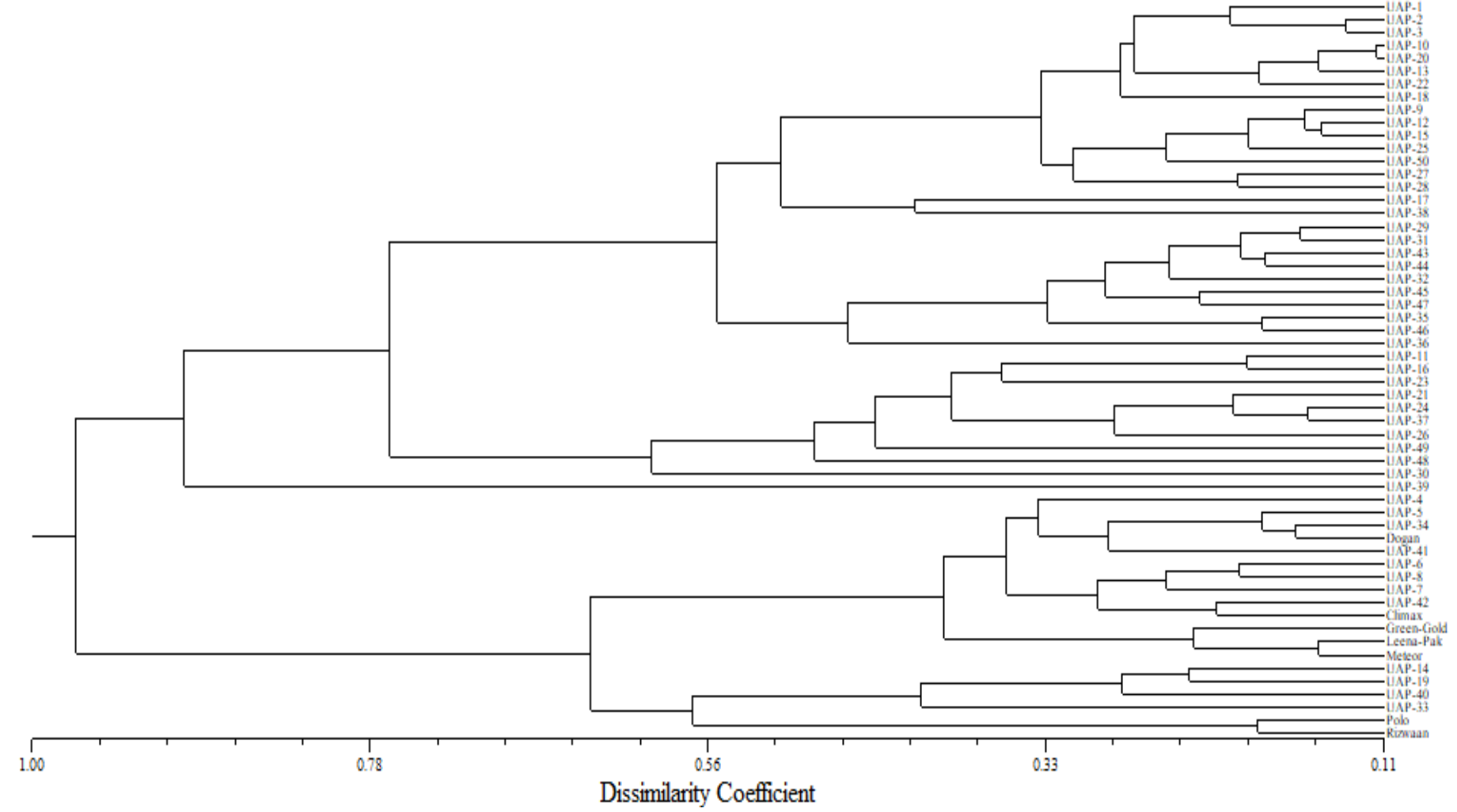

Figure 1: Dendogram of pea genotypes for qantitative traits.

1.00 to 9.94. Minimum Euclidean distances were manifested between Meteor and UAP-25 (1.00), Meteor and UAP-12 (1.01) and UAP-19 and UAP11 (1.01). Maximum Euclidean distance was observed between UAP-28 and UAP-7 (9.94) followed by Polo and UAP-17 (9.87) and UAP-48 and UAP15 (9.86).

Table 6: Eigen values of quantitative traits for first and second principal components (PCs) of garden pea genotypes.

\begin{tabular}{|c|c|c|}
\hline Traits & $\mathbf{P C}_{1}$ & $\mathrm{PC}_{2}$ \\
\hline Days to emergence & -0.20 & -0.47 \\
\hline Days to first picking & -0.54 & -0.58 \\
\hline Plant height & -0.76 & -0.29 \\
\hline Pods plant ${ }^{-1}$ & -0.89 & 0.10 \\
\hline Pod length & 0.03 & 0.83 \\
\hline Seeds pod ${ }^{-1}$ & -0.03 & 0.73 \\
\hline Hundred green seeds weight & -0.61 & 0.60 \\
\hline Hundred green pods weight & -0.46 & 0.77 \\
\hline Green pod yield & -0.77 & 0.36 \\
\hline
\end{tabular}

Cluster analysis for quantitative traits grouped pea genotypes into five distinct clusters at a dissimilarity level of 0.61 (Figure 1). The first cluster comprised
27 genotypes namely UAP-1, UAP-2, UAP-3, UAP10, UAP-20, UAP-13, UAP-22, UAP-18, UAP-9, UAP-12, UAP-15, UAP-25, UAP-50, UAP-27, UAP-28, UAP-17, UAP-38, UAP-29, UAP-31, UAP-43, UAP-44, UAP-32, UAP-45, UAP-47, UAP-35, UAP-46 and UAP-36. These genotypes were tall (upto $135 \mathrm{~cm}$ plant height), late maturing (upto 80 days to first picking) and high yielding (upto 8.5 tons ha $\mathrm{h}^{-1}$ ). The second cluster contained 10 genotypes namely UAP-11, UAP-16, UAP-23, UAP-21, UAP-24, UAP-37, UAP-26, UAP-49, UAP-48 and UAP-30 with moderate value for seeds pod ${ }^{-1}$ (upto 5 ), pods plant ${ }^{-1}$ (upto 25 ) and green pod yield (6 tons $\left.\mathrm{ha}^{-1}\right)$. Third cluster contained only one genotype having short pods $(4.07 \mathrm{~cm})$ and minimum number of seeds pod $^{-1}(4.00)$. The forth cluster had 13 genotypes namely UAP-4, UAP-5, UAP-34, Dogan, UAP-41, UAP-6, UAP-8, UAP-7, UAP-42, Climax, Green Gold, Leena Pak and Meteor with medium plant height (upto $65 \mathrm{~cm}$ ), optimum maturity duration (upto 65 days) and relatively long pods (upto $8 \mathrm{~cm}$ ). The fifth cluster contained 6 genotypes namely UAP14, UAP-19, UAP-40, UAP-33, Polo and Rizwaan. These genotypes were having similarity in their plant height (upto $58 \mathrm{~cm}$ ), 100-green seed weight (upto 26 g) and green pod yield (upto 5 tons $\mathrm{ha}^{-1}$ ). 


\section{Conclusions and Recommendations}

Based on the findings it is concluded that there were significant differences among genotypes of pea for yield and yield associated traits. UAP-47 and UAP29 were promising pea genotypes in terms of pod yield with the highest values for days to emergence, pods plant ${ }^{-1}$, hundred green seeds weight and green pod yield. Pea varieties namely Leena Pak and $\mathrm{Me}-$ teor were observed as genotypes with early maturity traits as these varieties took minimum days to first picking among the studied pea genotypes. Maximum value for pod length, seeds pod ${ }^{-1}$ and hundred green pods weight was recorded for variety Green Gold. Plant height, pods plant ${ }^{-1}$, pod length, 100-green seed weight and 100-green pod weight displayed significantly positive correlation with green pod yield. Pea genotypes Leena Pak, UAP-29 and UAP-47 and Green Gold showed superior performance for maturity, yield and yield-related traits and are recommended for testing across locations. Moreover, the genetic potential of these genotypes for the desired traits could be exploited in future pea breeding programs.

\section{Novelty St}

Pea is an important vegetable crop of Pakistan. In Pakistan, limited number of low yielding pea genotypes are being used commercially resulting in reduced pea yield. This study helped in the identification of desirable high yielding pea genotypes. Moreover, the genotypes for desirable traits could be used in pea breeding programs to broaden the gene pool of this important vegetable crop.

\section{Author's Contribution}

Faiza Aman: Conducted research, collected data, literature review, data analysis and man-uscript writeup. The research is part of PhD Dissertation of Faiza Aman working under the supervision of Dr. Neelam Ara and Dr. Syed Mehar Ali Shah.

Neelam Ara: Research supervision, data Analysis Syed Mehar Ali Shah: Designed research, research supervision, data interpretation manuscript write-up.

\section{Conflict of interest}

The authors have declared no conflict of interest.

\section{Refrences}

Ahmad, H., B S. Rauf, C.M. Rafiq, A.U. Mohsin and A. Iqbal. 2014. Estimation of genetic variability in pea (Pisum sativum L.). J. Glob. Innov. Agric. Soc. Sci., 2(2): 62-64. https://doi. org/10.17957/JGIASS/2.2.496

Ali, B., Raziuddin, I. Ullah, Farhatullah, S. Khan, S.T. Shah, M. Ali, M.A. Khan and F. Khan. 2019. Assessment of genetic variability, genetic advance and correlation coefficient in quantitative traits of field pea (Pisum sativum L.). Genotypes Biosci. Res., 16(4): 3769-3780.

Anant, B., S. Jagdish, K.P. Singh and R. Mathura. 2006. Plant growth, yield and quality attributes of garden pea as influenced by organic amendments and biofertilizers. Indian J. Hort., 63(3): 464- 466.

Azmat, M.A., N.N. Nawab, A.A. Khan, M. Ashraf, S. Niaz and K. Mahmood. 2011. Characterization of pea germplasm. Int. J. Veg. Sci. 17: 246-258. https://doi.org/10.1080/1931 5260.2010 .544380

Bashir, S., S.Z.A. Shah, R.M.M. Naz, A. Hamid, S. Anjum, N. Zahid and A. Afzal. 2019. Physicochemical evaluation of field pea (Pisum sativum L.) landraces under rainfed conditions of AJK-Pakistan. Pure Appl. Biol., 8(2): 10331042.

Bashir, I., S. Ishtiaq, S. Fiaz and M. Sajjad. 2014. Association of yield attributing traits in pea (Pisum sativum L.) Germplasm. M.Sc. thesis. University of Agriculture, Faislabad. pp. 1-179.

Bhuvaneswari, S., S.K. Sharma, P. Punitha, K.S. Shashidhar, K.L. Naveenkumar and N. Prakash. 2016. Evaluation of morphological diversity of field pea (Pisum sativum L.) germplasm under sub-tropical climate of Manipur. Legume Res., 2(40): 215-223.

Bozoglu, H.E., A. Peksen and A. Gulumser. 2007. Determination of the yield performance and harvesting periods of fifteen pea (Pisum sativum L.) cultivars sown in autumn and spring. Pak. J. Bot., 39(6): 2017-2025.

Ceyhan, E. and M.A. Avci. 2005. Combining ability and heterosis for grain yield And some yield components in pea (Pisum sativum L.). Pak. J. Bio. Sci. 8(10): 1447-1452.

Dar, S.A., M.H. Khan, M.I. Makhdoomi and S. M.Sultan. 2017. Combining ability of yield and yield attributing traits in field pea (Pisum satioum L.). Electr. J. Plant Breed., 8(3): 927-932. https://doi.org/10.5958/0975928X.2017.00115.6 
Espósito, M.A., E.A. Martin, V.P. Cravero, D. Liberatti, F.S. López Anido and E.L. Cointry. 2009. Relationships among agronomic traits and seed yield in pea. BAG. J. Basic. Appl. Gen. 20: $1-8$.

FAOSTAT. Food and Agriculture data.2018.http:// www.fao.org/faostat/en/\#home (accessed on 8 January 2020).

FAOSTAT. 2016. http://www.fao.org/faostat/ en/\#home (accessed on 8 January 2018).

Gixhari, B., H. Vrapi and V. Hobdari. 2014. Morphological characterization of pea (Pisum sativum L.) genotypes stored in Albanian gene bank. Alb. J. Agri. Sci., pp. 169.

Habtamu, S. and F. Million. 2013. Multivariate analysis of some Ethiopian field pea (Pisum sativum L.) genotypes. Intl. J. Mol. Bio. 5(6): 78-87.

Khan, T.N., A. Ramzan, G. Jillani and T. Mehmood. 2013. Morphological performance of peas (Pisum sativum) genotypes under rainfed conditions of Potowar region. J. Agric. Res., 51(1): 51-60.

Kosev, V.I. 2013. Inheritance of earliness and vegetation period in pea (Pisum sativum L.) genotypes. Banat's J. Biotech,. 4(8): 35. https:// doi.org/10.7904/2068-4738-IV(8)-35

Kumar, J. and S. Abbo, 2001. Genetics of flowering time in chickpea and its bearing on productivity in semiarid environments. Adv. Agron., 72: 107-138. https://doi.org/10.1016/S00652113(01)72012-3

Kumar, R., M. Kumar, S. Kumar and A. Kumar. 2016. Screening of pea (Pisum sativum L.) germplasm for growth, yield and resistance against powdery mildew under mid-hill conditions of Himachal Pradesh. Int. J. Biores. Stress Manage., 7(1): 119-125. https://doi. org/10.23910/IJBSM/2016.7.1.1286

Kumar, M., M.S. Jeberson, N.B. Singh, R. Sharma and R.S.Patel.2019. Analysis of trait association and principal component of variability in field pea (Pisum sativum L.) genotypes. Pharma Inn. J., 7(8): 437-441.

Lakic, Z., S. Stankovic, S. Pavlovic, S. Krnjajic and V. Popovic. 2019. Genetic variability in quantitative traits of field pea (Pisum sativum L.) genotypes. Czech J. Genet. Plant Breed. 55 (1): 1-7. https://doi.org/10.17221/89/2017CJGPB

Monpara, B.A. and H.R. Dhameliya. 2013.
Genetic behaviour of earliness related traits and seed yield in chickpea (Cicer arietinum L.). Pak. J. Biol. Sci., 16(18):955-959. https:// doi.org/10.3923/pjbs.2013.955.959

Muhammad, S., S. Bacha, M. Arshad, R. Din and A. Ghafoor. 2009. Genetic diversity for determining yield potential and selection criteria in Pisum sativum L., genetic resources. Pak. J. Bot., 41(6): 2987-2993.

Nawab, N.N., G.M. Subhani, K. Mahmood and Q. Shakil. 2009. Genetic variability, correlation and path analysis studies in garden pea (Pisum sativum L.). AGRIS, 46(4): 333-340.

Pallavi, A.S. and K.K. Pandey. 2013. Estimation of heritability on pea (Pisum sativum L.). Ad. Biores. 4: 89-92.

Rahman, A.U., V. Katoch and S. Sharma. 2019. Studies on variability, correlation and path analysis in garden pea (Pisum satioum L.) for pod yield and its related traits under natural farming conditions. J. Pharm. Phytochem., 435-438.

Ramzan, A., T. Noor, T.N. Khan and A. Hina. 2014. Correlation, cluster and regression analysis of seed yield and its contributing trait in Pea (Pisum sativum L.). J. Agric. Res., 52(4): 481488.

Shah, B.H., F.S. Hamid, S.U. Islam, F. Ahmad, S. Aslam and N. Khan. 2016. Evaluation of different pea (Pisum sativum L.) genotypes for yield and other attributes at Shinkiari, Mansehra. Pak. J. Agric. Res., 29(4): 323-330.

Singh, S., V. Verma, B. Singh, V.R. Sharma and M. Kumar. 2019. Genetic variability, heritability and genetic advance studies in pea (Pisum sativum L.) for quantitative characters. Indian J. Agric. Res., 53(5): 542-547. https://doi. org/10.18805/IJARe.A-5245

Singh,A.K and C.P. Srivastava.2015. Effect of plant types on grain yield and lodging resistance in pea (Pisum satioum L.). Indian J. Genet. 4(75): 69-74.

Sharma, V. K. and L. Bora. 2013. Studies on genetic variability and heterosis in vegetable pea (Pisum satioum L.) under high hills condition of Uttarakh, India. Afr. J. Agric. Res. 8(18): 18911895.

Smitchger, J. and N.F. Weeden. 2018. The ideotype for seed size: A model examining the relationship between seed size and actual yield in pea. Int. J. Agr., 4(7): 1-7. https://doi. 
org/10.1155/2018/9658707

Taran, B., C. Zhang, T. Warkentin, A. Tullu and A. Vandenberg. 2005. Genetic diversity among varieties and wild species accessions of pea (Pisumsativum L.) based on molecular markers and morphological and physiological characters. Genome, 48(2): 257-272. https:// doi.org/10.1139/g04-114

Tiwari, G. and G.R. Lavanya. 2012. Genetic variability, character association and component analysis in F4 generation of field pea (Pisum sativum var. arvense L.). Karnataka J. Agric.
Sci., 25: 173-175.

Umar, H.M.I., S. Ur-rehman, M. Bilal, S. Atif, H. Naqvi and S.A. Manzoor. 2014. Evaluation of genetic diversity in pea (Pisum sativum) based on morpho-agronomic characteristics for yield and yield associated traits. J. Biodivers. Environ. Sci., 4(5): 323-328.

Yadav, H., Y.V. Singh and P. Massey. 2018. Study of heterosis and inbreeding depression for yield and quality traits in garden pea (Pisum satioum var. (L.) hortense). Int. J. Chem. Stud., 6(5): 1229-1235. 